\title{
The identification of porphyry-skarn ore system in the Yichun Area, NE China: evidence from $\mathrm{U}-\mathrm{Pb}$ and $\mathrm{Re}-$ Os geochronology
}

\author{
X.X. GU ${ }^{1}$, Y.M. ZHANG ${ }^{1}$, R.P. LIU ${ }^{2}$, J.L. WANG ${ }^{1}$ \\ ${ }^{1}$ State Key Laboratory of Geological Processes and Mineral \\ Resources, China University of Geosciences, Beijing \\ 100083, China (xuexiang_gu@cugb.edu.cn) \\ ${ }^{2}$ Beijing Research Institute of Uranium Geology, Beijing \\ 100029, China
}

The Yichun area is located in the east part of the Central Asian-Mongolian orogenic belt, Heilongjiang, NE China. It is well known for hosting a great deal of epithermal gold deposits and porphyry molybdenum deposits of Yanshanian in the Xiaoxing'anling-Zhangguangcailing metallogenic belt. Recently, a Permo-Triassic porphyry-skarn ore system was identified based on $\mathrm{U}-\mathrm{Pb}$ and $\mathrm{Re}-\mathrm{Os}$ dating of two adjacent deposits at the northwest margin of the Meifeng volcanic basin in our study. The Gaogangshan deposit is a newly discovered medium-sized porphyry Mo deposit hosted mainly by S-type granitic rocks. LA-ICP-MS U-Pb dates of zircon in mineralized granitic porphyry yielded a weighted average age of $259.9 \pm 2.0 \mathrm{Ma}$. Re-Os dating of molybdenum ore gave an isochron age of $250.2 \pm 1.4 \mathrm{Ma}$ and a weighted average age of $247 \pm 6 \mathrm{Ma}$, which slightly postdate the emplacement of the granite. The Baoshan $\mathrm{Cu}-\mathrm{Mo}-\mathrm{W}$ deposit, located at $\sim 5 \mathrm{~km}$ to the north of the Gaogangshan deposit, is a typical skarn deposit. Orebodies occur at the contact zone between granitoid rocks and carbonate rocks of the Cambrian Qianshan Formation. LA-ICP-MS U-Pb zircon analyses yield a concordia age of $248.4 \pm 2.1 \mathrm{Ma}$ for ore-related granodiorite. Re-Os dating of molybdenum ore gave an isochron age of $242.0 \pm 0.98 \mathrm{Ma}$ and a weighted average age of $241.9 \pm 1.7 \mathrm{Ma}$. The consistent ages of magmatism and mineralization at Gaogangshan and Baoshan coincide with collisional to post-collisional tectonism in the region, resulting from the interaction between the Jiamusi-Mongolia block and the northeastern part of the Sino-Korean Plate. Both of them belong to a porphyry-skarn mineralization system related to the Permo-Triassic magmatism. The recognition of this Indosinian mineralization system has significance to the regional ore-prospecting and coexploration in NE China.

The research was funded by the National Natural Science

Foundation of China under grant of 41572062. 